\title{
Gonadotrophin-releasing hormone antagonist arrests premeiotic germ cell proliferation but does not inhibit meiosis in the male monkey: a quantitative analysis using 5-bromodeoxyuridine and dual parameter flow cytometry
}

\author{
G F Weinbauer, J Schubert, C-H Yeung, G Rosiepen and \\ E Nieschlag \\ Institute of Reproductive Medicine of the University, Domagkstrasse 11, D-48129 Münster, Germany \\ (Requests for offprints should be addressed to E Nieschlag)
}

\begin{abstract}
Meiosis constitutes a crucial phase of spermatogenesis since the recombination of genetic information and production of haploid round spermatids need to be achieved. Although it is well established that gonadotrophic hormones are required for completion of the spermatogenic process, little is known about the dynamic and kinetic aspects of development of spermatocytes into spermatids and its endocrine control in the primate. In this study, S-phase germ cells were labelled using 5-bromodeoxyuridine (BrdU) incorporation and were then followed throughout meiosis under normal conditions and following GnRH antagonist (ANT)-induced gonadotrophin withdrawal in a nonhuman primate model, the cynomolgus monkey (Macaca fascicularis). Adult animals received either vehicle $(\mathrm{VEH}, n=4)$ or the ANT cetrorelix $(n=5)$ throughout 25 days. On day 7 all animals received a bolus injection of BrdU. A biopsy was performed after $3 \mathrm{~h}$, one testis was removed 9 days later (day 16 of treatment) and the other testis after 18 days (day 25 of treatment). Serum testosterone and inhibin levels, and testis weight were reduced $(P<0.05)$ by ANT treatment. BrdU localized to pachytene spermatocytes 9 days after $\operatorname{BrdU}$ and to round spermatids 18 days after BrdU in both groups, demonstrating that BrdU-labelled pachytene spermatocytes had undergone meiosis. Flow cytometric analysis revealed that the relative number and number per testis of BrdU-tagged
\end{abstract}

2C and 4C cells were reduced significantly $(P<0 \cdot 05)$ within 16 days of ANT treatment. Numbers of $1 \mathrm{C}$ cells were lowered by day 25 . The cell ratio for $1 \mathrm{C}: 4 \mathrm{C}$ was similar with VEH and ANT $(P>0 \cdot 05)$. These findings indicate that ANT reduced the number of cells available for meiosis but did not alter the rate of transition into round spermatids. Unexpectedly, however, the stagedependent progression of BrdU-tagged round spermatids was significantly $(P<0 \cdot 05)$ retarded under ANT as seen from the frequency of tubules containing BrdU-labelled round spermatids. The average duration of spermatogenic cycle was slightly prolonged $(9 \cdot 8$ days in the VEH group and 10.8 days in the ANT group $(P=0.09))$. Since no atypical germ cell associations could be found, it remains unclear whether this slight prolongation is entirely due to altered spermatid progression or whether earlier phases are affected. We conclude for the nonhuman primate that (1) BrdU-labelling of premeiotic germ cells is suitable for tracing their meiotic transition into postmeiotic cells, (2) unlike in the rat, gonadotrophin suppression initially affects premeiotic cell proliferation and thus the number of cells available for meiosis, (3) the meiotic process continues quantitatively despite gonadotrophin deficiency and (4) prolonged gonadotrophin deficiency might alter the timing of germ cell development.

Journal of Endocrinology (1998) 156, 23-34

\section{Introduction}

Mammalian spermatogenesis is a highly complex process comprising several entirely different events, i.e. multiple mitotic divisions of diploid spermatogonia, meiotic division of tetraploid spermatocytes giving rise to haploid spermatids and, finally, the morphological differentiation of round spermatids into elongated spermatids. These processes take place in a topographically and chronologically coordinated manner. Meiosis is a critical phase of gametogenesis for several reasons since recombination of the genetic information, reduction of chromosome numbers and formation of spermatids need to be accomplished. The overall spermatogenic process is under endocrine control and lack of gonadotrophic support to the testis provokes a progressive loss of germ cells (Weinbauer \& Nieschlag 1996). 
However, the testicular response to gonadotrophin deficiency seems to be different between rodents and primates. Detailed histological studies in the rat identified a specific loss of spermatocytes and spermatids as the earliest lesion following gonadotrophic hormone deprivation (Russell \& Clermont 1977, Sinha-Hikim \& Swerdloff 1993, O'Donnell et al. 1996). In the nonhuman primate, loss of spermatogonia (Weinbauer et al. 1991) and meiotic arrest (Aravindan et al. 1993) have been suggested. Prolonged withdrawal of gonadotrophic hormones eliminates spermatids, spermatocytes and even differentiated spermatogonia in the monkey (Marshall et al. 1986, Weinbauer et al. 1991). In contrast, some spermatocytes and round spermatids are retained despite continued elimination of luteinizing hormone (LH) and follicle-stimulating hormone (FSH) in the rat (Sun et al. 1990, Chandolia et al. 1991a,b, McLachlan et al. 1995).

Another difference between rodents and primates has been reported with respect to efficacy of spermatogenesis and daily sperm production. Daily sperm production $\left(10^{6} / \mathrm{g}\right.$ testis) was $10-24$ in rats (Wing \& Christensen 1982, Russell \& Petersen 1984), 4-5 in nonhuman primates (Gopalkrishnan et al. 1987) and 3-7 in men (Johnson et al. 1980). In other species such as rabbit, bull, stallion, ram and boar, daily sperm production achieved values beyond $12\left(10^{6} / \mathrm{g}\right.$ testis) and it would appear that, in general terms, the primate testis produces comparatively low numbers of sperm per weight unit of testicular parenchyma (see for example Sharpe 1994). It has also been reported from post-mortem analysis of human testicular tissue that meiotic transition is associated with a 40-60\% germ cell loss (Johnson et al. 1990, 1992). For the rat, based on spermatocyte:spermatid conversion rates, cell loss is much less pronounced (Wing \& Christensen 1982, Zhengwei et al. 1990, Chandolia et al. 1991a, McLachlan et al. 1995).

The mechanisms underlying the differences among rats and primates in the testicular response to gonadotrophin withdrawal and the comparatively lower germ cell production rate of the primate testis are not known, but such knowledge would have important implications for dealing with male infertility and designing male contraceptives. For primates, little is known about the dynamic and kinetic aspects of development of spermatocytes into spermatids and the role of gonadotrophins in this process. Germ cells in the S-phase of the cell cycle can be identified by the incorporation and localization of 5-bromodeoxyuridine (BrdU) (Thoolen 1990, van de Kant \& de Rooij 1992) and can be traced during the spermatogenic cycle in the rat (Rosiepen et al. 1994). Systematic investigation of these aspects of germ cell proliferation in man is not possible because of ethical constraints. We, therefore, have initiated studies on this topic in a nonhuman primate model, the cynomolgus monkey (Macaca fascicularis) since, in terms of the endocrine regulation of spermatogenesis, this primate species has proved to be a suitable animal model for the human (Weinbauer \& Nieschlag 1988, 1996). S-phase germ cells were labelled using BrdU incorporation and were then followed throughout meiosis under normal conditions and following gonadotrophin-releasing hormone (GnRH) antagonist (ANT)-induced gonadotrophin withdrawal using quantitative histological and flow cytometrical techniques.

\section{Materials and Methods}

\section{Animals}

Ten adult cynomolgus monkeys (Macaca fascicularis), weighing between 4.4 and $6.3 \mathrm{~kg}$, were caged individually and maintained under defined environmental conditions as previously described (Weinbauer et al. 1994). Animals were fed standard monkey pellet food supplemented with fresh fruit and had free access to tap water. The study was undertaken in accordance with the German Federal Law on the Care and Use of Laboratory Animals (license $72 / 92)$.

\section{Experimental design}

Animals were randomly allocated to the treatment groups ( $n=5$ /group) and either received daily s.c. injections of vehicle $(5 \cdot 25 \%$ glucose in saline, VEH) or the GnRH antagonist cetrorelix (ANT) at a dose of $450 \mu \mathrm{g} / \mathrm{kg}$ for 25 days. On study day 7 all animals received a single i.v. injection of BrdU under ketamine hydrochloride sedation $(8 \mathrm{mg} / \mathrm{kg}$, Ketamine, Parke-Davis, Munich, Germany). The dosage for BrdU was derived from clinical studies in which i.v. infusions of $150-700 \mathrm{mg} \mathrm{BrdU} / \mathrm{m}^{2}$ surface area had been given without myelotoxic effects (Hoshino et al. 1985). Following these studies a dose of $590 \mathrm{mg} / \mathrm{m}^{2} \mathrm{BrdU}$ (corresponding to $33 \mathrm{mg} / \mathrm{kg}$ ) was administered as a single i.v. injection of a $2 \%$ solution $\mathrm{BrdU}$ in $0.9 \% \mathrm{NaCl}$ for labelling only the generation of germ cells that are in the S-phase of the cell cycle at the time of BrdU application. Three hours after BrdU application a testicular biopsy was performed for the localization of BrdU. One testis was removed $9 \pm 0 \cdot 1$ days after BrdU injection (day 16 of treatment) and the other testis after $18 \pm 0 \cdot 1$ days (day 25 of treatment) for histological and flow cytometrical analyses. Blood was collected from the cubital vein for the analysis of serum $\mathrm{T}$ and inhibin concentrations prior to and on days 7, 16, 21 and 25 of the study under ketamine hydrochloride sedation.

\section{Tissue processing and localization of $\mathrm{BrdU}$}

Testicular biopsy material was placed in Carnoy's fluid. Testes were excised, weighed to the nearest $0.01 \mathrm{~g}$, and cut into slabs that were fixed in Carnoy's or Bouin's fluid. Specimens were subsequently dehydrated and embedded 
in Paraplast following routine procedures. Sections $(3 \mu \mathrm{m})$ were cut from pre-cooled paraffin blocks for histological analysis and immuncytochemical localization of BrdU by immunogold-silver staining. For immunolocalization, sections were deparaffinized, dehydrated and incubated with periodic acid in a microwave oven (BIORAD 2500, München, Germany; $60 \%$ maximal power at $50{ }^{\circ} \mathrm{C}$ ) for $30 \mathrm{~min}$, rinsed in tap and distilled water and followed by Schiff's reagent for $30 \mathrm{~min}$. Periodic acid treatment served to hydrolyze the DNA allowing access of the BrdU antibody and to provide staining of the acrosome for staging of the spermatogenic process (van de Kant \& de Rooij 1992). A monoclonal antibody against BrdU (Dako Diagnostica, Hamburg, Germany) was used at a dilution of 1:20 for $60 \mathrm{~min}$ and nonspecific binding was blocked using $5 \%$ normal goat serum. Gold-labelled goat anti-mouse IgG (Amersham Ltd, Amersham, Bucks, UK) at a dilution of 1:40 served as second antibody. Silver enhancement solution (Amersham Ltd) was added for $11 \mathrm{~min}$. Sections were then counterstained with haematoxylin, dehydrated and mounted in Merckoglas.

\section{Dual parameter flow cytometry}

Snap-frozen testicular tissue, obtained on days 16 and 25 of the study, was stored at $-80{ }^{\circ} \mathrm{C}$ until analysis. Tissue was blade-minced in C100T solution (citrate and tween20), homogenized (Ultra-Turrax T25, Janke \& Kunkel, Heppenheim, Germany), further incubated for $30 \mathrm{~min}$ in C100T and transferred into absolute ethanol for $\geq 24 \mathrm{~h}$. Samples were then centrifuged, the pellet was resuspended in $2 \mathrm{M} \mathrm{HCl} /$ pepsin and incubated for $45 \mathrm{~min}$ at room temperature under constant agitation. Washing steps included phosphate-buffered saline. Monoclonal antibody against BrdU (Dako Diagnostica), diluted 1:10, was added and incubation lasted for $30 \mathrm{~min}$ in the dark. FITCconjugated goat anti-mouse IgG (Sigma Chemicals, St Louis, MO, USA) was used as the secondary antibody diluted 1:10 with 30 min incubation in the dark. Following centrifugation at $1300 \mathrm{~g}$, propidium iodide $(5 \mu \mathrm{g} / \mathrm{ml}$, Sigma Chemicals) was added to the pellet, gently vortexed and incubated for $60 \mathrm{~min}$ in the dark. A total of $16.3 \pm 1.7 \mathrm{mg}$ testicular tissue (ranging between 9 and $33 \mathrm{mg}$ ) were used for determination of the number of $1 \mathrm{C}$, $2 \mathrm{C}$ and $4 \mathrm{C}$ cells (identified through labelling with propidium iodide) and of the number of $1 \mathrm{C}, 2 \mathrm{C}$ and $4 \mathrm{C}$ cells labelled with BrdU (identified by FITC emission).

Analysis was performed using the Coulter flow cytometer EPICS XL (Coulter, Krefeld, Germany) equipped with a $15 \mathrm{~mW}$ argon-laser at an excitation wavelength of $488 \mathrm{~nm}$. In order to correct for non-specific FITC-signals, testicular tissue collected from an adult, intact cynomolgus monkey, not treated with BrdU, was processed as described above. Forward scatter signals were used as trigger signals and fluorescence emissions were measured by photomultiplier detectors with a band pass filter 525BP
(504-540 nm) for light reflected by the dichroic 550DL filter for FITC, and a 620BP filter after a 660DL long pass filter for propidium iodide. Cell debris and aggregates were eliminated from analysis by gating. Each category of cells identified by the propidium iodide signal as $1 \mathrm{C}, 2 \mathrm{C}$ or 4C was analyzed for positive FITC signals. 2C cells are spermatogonia, secondary spermatocytes and somatic cells, 4C cells represent cells in mitotic or first meiotic division after DNA synthesis (primary spermatocytes, somatic cells and spermatogonia in G2) and 1C refers to haploid germ cells (Toppari et al. 1985).

\section{Histological analysis}

All sections were coded and evaluated in a randomized manner. The exposure to ANT was limited to 25 days because it is known from previous work that identification of spermatogenic stages is still possible whereas at later time points identification would become difficult or impossible owing to the progressive loss of round and elongated spermatids (Weinbauer et al. 1991). Germ cell-specific and stage-specific distribution of BrdU-labelled germ cells was performed. Spermatogenesis was divided into 12 stages according to Clermont \& Leblond (1959). Frequencies were determined for spermatogenic stages I-IV (pooled), V, VI, VII, VIII and XI-XII (pooled). The number of seminiferous tubules containing BrdU-labelled germ cells in the various stages on days 9 and 18 after $\operatorname{BrdU}$ administration was determined and is referred to as the BrdU-staining frequency. Between 507 and 684 seminiferous tubule sections were evaluated per time point and animal for assessment of stage and staining frequency. The duration of one seminiferous cycle was calculated for each animal on the basis of individual stage frequencies, BrdUstaining frequencies at both time points after BrdU injection and the time interval between the two time points (Rosiepen et al. 1994, 1995, 1997).

The proportion of pachytene spermatocytes and round spermatids containing BrdU was also determined in stages $\mathrm{V}$ and VI by counting the total number of either pachytene spermatocytes (day 9 after BrdU) or round spermatids (day 18 after BrdU) and how many cells of these type contained BrdU. Randomly selected blocks were sectioned and analyzed. A total of 615-1466 pachytene spermatocytes (day 16) and 232-2491 round spermatids (day 25) in the respective stages were analyzed in each specimen. Since data are interpreted only with respect to relative numbers among the same cell type, corrections for tissue shrinkage and ANT-induced testicular involution were not necessary.

\section{Serum testosterone and inhibin}

Serum testosterone was measured by RIA using a commercial kit (DSL-4100, Diagnostic Systems Laboratories, Sinsheim, Germany). Intra- and interassay coefficients of 

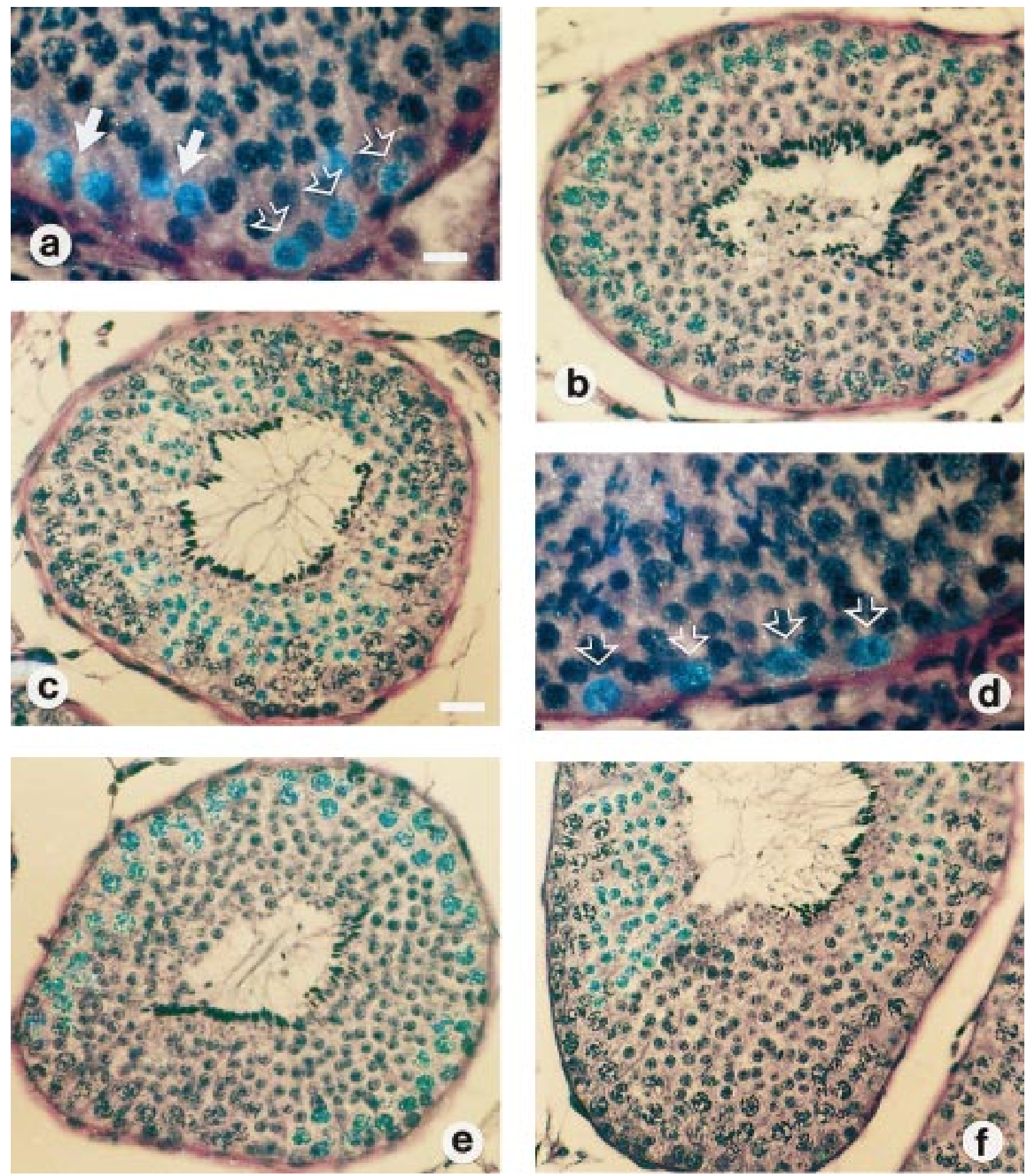

Figure 1 Immunolocalization of BrdU in testis of VEH-treated (a,b,f) and ANT-treated (c,d,e,) monkeys. (a,d) $3 \mathrm{~h}$ after BrdU injection: spermatogonia (open arrows) and early spermatoctes (closed arrows) are labelled; (b,e) 9 days after BrdU injection: pachytene spermatocytes are labelled; $(\mathrm{c}, \mathrm{f}) 18$ days after BrdU injection: round spermatids are labelled (blueish colour), note the lower number of spermatids following ANT treatment $(\mathrm{c})$. Tubules in $(\mathrm{b}, \mathrm{c})$ are in stage $\mathrm{Vl}$; tubules in $(\mathrm{e}, \mathrm{f})$ are in stage $\mathrm{VI}$ and VII (where spermiation has occurred). Sections were counterstained with periodic acid-Schiff's base and haematoxylin. Bars indicate $9 \mu \mathrm{m}$ for (a, d) and $20 \mu \mathrm{m}$ for $(b, c, e, f)$. 
variation were 6.5 and $13.4 \%$ respectively, and the detection limit was $0.17 \mathrm{nmol} / \mathrm{l}$. Serum inhibin was measured by a RIA validated for cynomolgus monkey serum (Fingscheidt et al. 1989). This assay detects $\alpha$ subunit-containing forms including inhibin $\mathrm{B}$ and the pro $\alpha-\mathrm{C}$ protein and was found to measure FSH-dependent inhibin in macaque monkeys (Weinbauer et al. 1991, Arslan et al. 1993). Hence, serum inhibin levels are used as an indication of circulating FSH activity. All samples were assayed in duplicate in a single assay. The detection limit was $1.2 \mathrm{U} / \mathrm{ml}$ serum and the within assay precision was $2 \cdot 8 \%$.

\section{Statistical evaluation}

Data are presented as means \pm S.E.M. Germ cell ratios were tested by Student's $t$-test. Other parameters were tested by two-way ANOVA for repeated measures followed by Student-Newman-Keuls test. Relative frequencies and percentage values were subjected to arcsin transformation prior to statistical analysis. Probability levels of $P<0 \cdot 05$ were considered significant. Flow cytometric and histological data revealed abnormal spermatogenesis in one control animal and, hence, data from this animal were excluded from analysis.

\section{Results}

\section{Histological analysis of BrdU-labelled cells}

Three hours after BrdU bolus, spermatogonia and early spermatocytes displayed a BrdU signal (Fig. 1a and d). Sertoli cells containing BrdU were not seen whereas occasionally peritubular cells and interstitial cells displayed BrdU signal (not shown). The amount of biopsy material did not permit quantitative analysis of cellular staining proportions nor stage-related analysis but no qualitative differences of BrdU staining pattern could be seen between both groups. Nine days after BrdU administration, spermatocytes contained BrdU (Fig. 1b and e), and by day 18 after BrdU, spermatocytes and round spermatids were BrdU-positive (Fig. 1c and $\mathrm{f}$ ) in both experimental groups. A schematic representation of the stage-dependent distribution of BrdU-labelled germ cell types and their progression in a VEH-treated animal and an ANT-treated animal is depicted in Fig. 2.

\section{Flow cytometrical analysis of BrdU-labelled cells}

Between 0.02 and $0.07 \%$ of testicular cells emanated a FITC-signal above background in the animal that had not been exposed to BrdU. These signals were regarded as non-specific and were corrected for each category (1C, 2C and $4 \mathrm{C}$ ) during the analysis of all BrdU-exposed animals.
Coefficients of variation for repeated dual parameter analysis of three to four preparations from the same animal ranged between 4 and $9 \%$.

Relative numbers (percentages) of $2 \mathrm{C}$ and $4 \mathrm{C}$ cells labelled with $\mathrm{BrdU}$ (2C-BrdU, 4C-BrdU cells) were significantly lowered to 40 and $70 \%$ of $\mathrm{VEH}$ respectively, within 16 days of ANT treatment (Fig. 3). Proportions of $2 \mathrm{C}-\mathrm{BrdU}$ cells were also reduced on day 25 . When expressed as numbers per testis, $2 \mathrm{C}-\mathrm{BrdU}$ and $4 \mathrm{C}-\mathrm{BrdU}$ cells were reduced to 20 and $30 \%$ of VEH by day 16 and remained lower until day 25 (Fig. 3). For 1C cells, the proportion of BrdU-containing cells was negligible on day 16 (9 days after BrdU) in both groups $(<0 \cdot 5 \%$, Fig. 3). This observation correponds to the immunocytochemical findings (Figs 1 and 2). By day 25 (18 days after BrdU), relative numbers and numbers per testis of $1 \mathrm{C}-\mathrm{BrdU}$ cells were markedly increased in both groups (Fig. 3), reflecting the meiotic transition of spermatocytes into spermatids but these numbers were lower under ANT compared with VEH $(P<0 \cdot 05)$. The $1 \mathrm{C}-\mathrm{BrdU}: 4 \mathrm{C}-\mathrm{BrdU}$ cell ratio was similar for $\mathrm{VEH}$ and ANT groups $(P>0 \cdot 05)$. Combined numbers of BrdU-labelled and unlabelled 2C, 4C and 1C cells were significantly reduced on day 25 when compared with VEH $(P<0 \cdot 05$, data not shown).

\section{Kinetic analysis of spermatocyte-spermatid transition}

Stage frequencies did not differ significantly between VEH- and ANT-treated groups (Fig. 4). Differences were observed with regard to BrdU-staining frequencies, i.e. the number of tubules containing BrdU-labelled cells. By day 9 after BrdU injection, BrdU-staining frequencies (spermatocytes) for stages I-IV, V, VI, VII and VIII were similar for VEH and ANT groups $(P>0 \cdot 05)$. At the second time point (day 18 after BrdU), stage I-IV BrdU-staining frequencies were not significantly different $(P>0 \cdot 05)$ indicating that the duration of meiosis was not affected by ANT. However, the percentage of stage VI tubules containing BrdU-labelled germ cells (round spermatids) was significantly reduced $(P<0 \cdot 05)$ in the ANT group and no BrdU-tagged round spermatids could be discerned in stages VII and VIII. In contrast, 32\% of stage VII and 14\% of stage VIII tubules, on average, contained BrdU-labelled round spermatids in the VEH group. Thus, stagedependent progression of round spermatids over time was altered by ANT (see also Fig. 2). Stage IX-XII tubules were not analyzed since BrdU-labelled round spermatids did not advance beyond stage VIII. Calculation of the duration of this process provided an estimate of the length of one spermatogenic cycle. Cycle length appeared somewhat longer in the ANT group but this effect did not attain statistical significance (VEH group: 9.80 $\pm 0 \cdot 49$ days, range: $9 \cdot 10-11 \cdot 03$; ANT group: $10 \cdot 88 \pm 0 \cdot 25$ days, range: $10 \cdot 36-11 \cdot 45$ days $(P=0 \cdot 09))$. The ratio of BrdUlabelled:total number of germ cells in stages $\mathrm{V}$ and VI in VEH vs ANT group was $0.49 \pm 0 \cdot 07$ vs $0.48 \pm 0 \cdot 08$ 

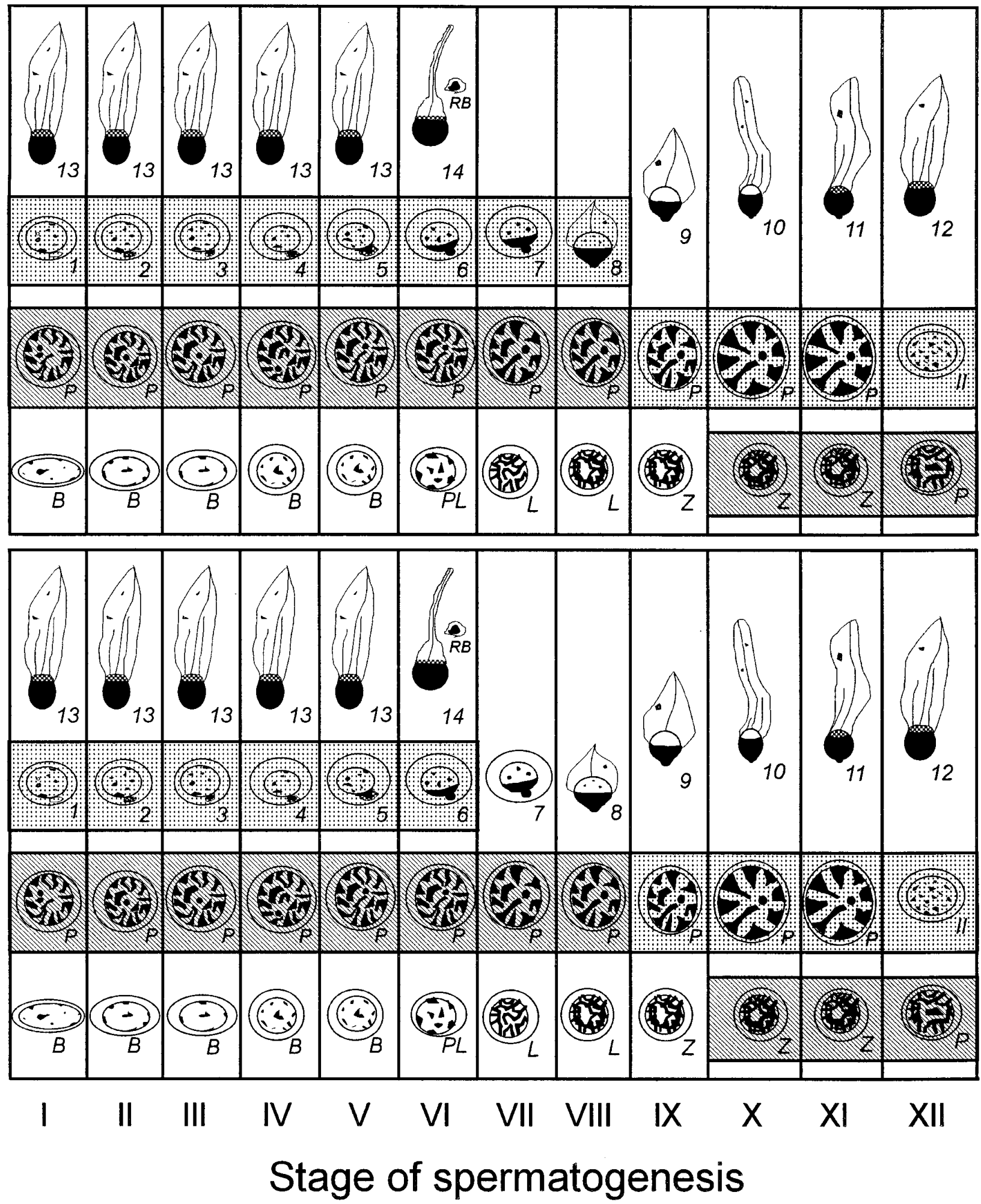

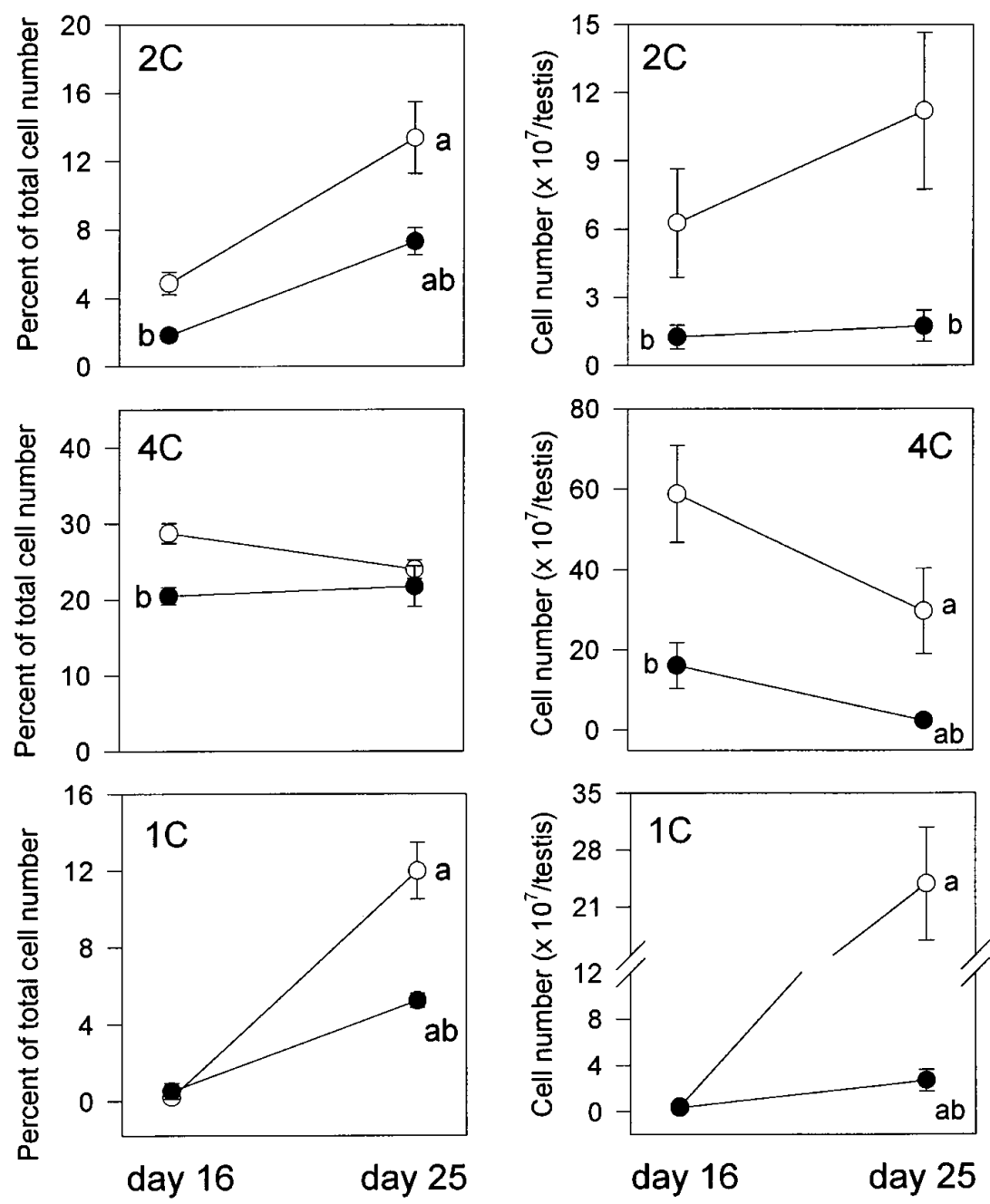

Figure 3 Flow cytometric quantification of testicular cells labelled with BrdU in VEH-treated $(\bigcirc)$ and ANT-treated $(\bullet)$ monkeys on day 16 (9 days after BrdU) and on day 25 (18 days after BrdU). Left panels depict the relative number of $2 \mathrm{C}, 4 \mathrm{C}$ and $1 \mathrm{C}$ cells; right panel depict cell number per testis. Data represent means \pm S.E.M. of four and five animals/group. ${ }^{a} P<0.05$ vs day 16 and ${ }^{b} P<0.05$ vs VEH. On day $16,1 \mathrm{C}$ cells (haploid cells) were not labelled with BrdU (see also Fig. 1b).

$(P>0 \cdot 05)$ for pachytene spermatocytes (day 9 after BrdU) and $0.33 \pm 0.12$ vs $0.22 \pm 0.08(P>0.05)$ for round spermatids (day 18 after BrdU). A specific alteration of spermatid progression would imply the existence of atypical cellular associations which, however, could not be observed.
Endocrine parameters and testis weight

Mean testosterone levels were between 18.9 and $32 \cdot 1 \mathrm{nmol} / 1$ in the VEH group throughout the study without significant change. Administration of ANT reduced testosterone concentrations from $20 \cdot 7 \mathrm{nmol} / 1$ at

Figure 2 Germ cell-specific and stage-specific localization of BrdU in a VEH-treated (upper panel) and an ANT-treated monkey (lower panel) at 9 days after BrdU (hatched area) and 18 days after BrdU (dotted area). In both animals, BrdU-labelled cells had progressed to stage VIII by day 9; whereas by day 18 the progression of round spermatids was less advanced (stage VI) for ANT than for VEH (stage VIII). The duration of the spermatogenic cycle is $9 \cdot 1$ days in the upper panel and $11 \cdot 45$ days in the lower panel. Roman numbers refer to the step of spermatid development. B, B-type spermatogonium; PL, preleptotene spermatocyte; L, leptotene spermatocyte; Z, zygotene spermatocyte; $\mathrm{P}$, pachytene spermatocyte. II, second meiotic division; RB, residual body. A-type spermatogonia are not shown. 

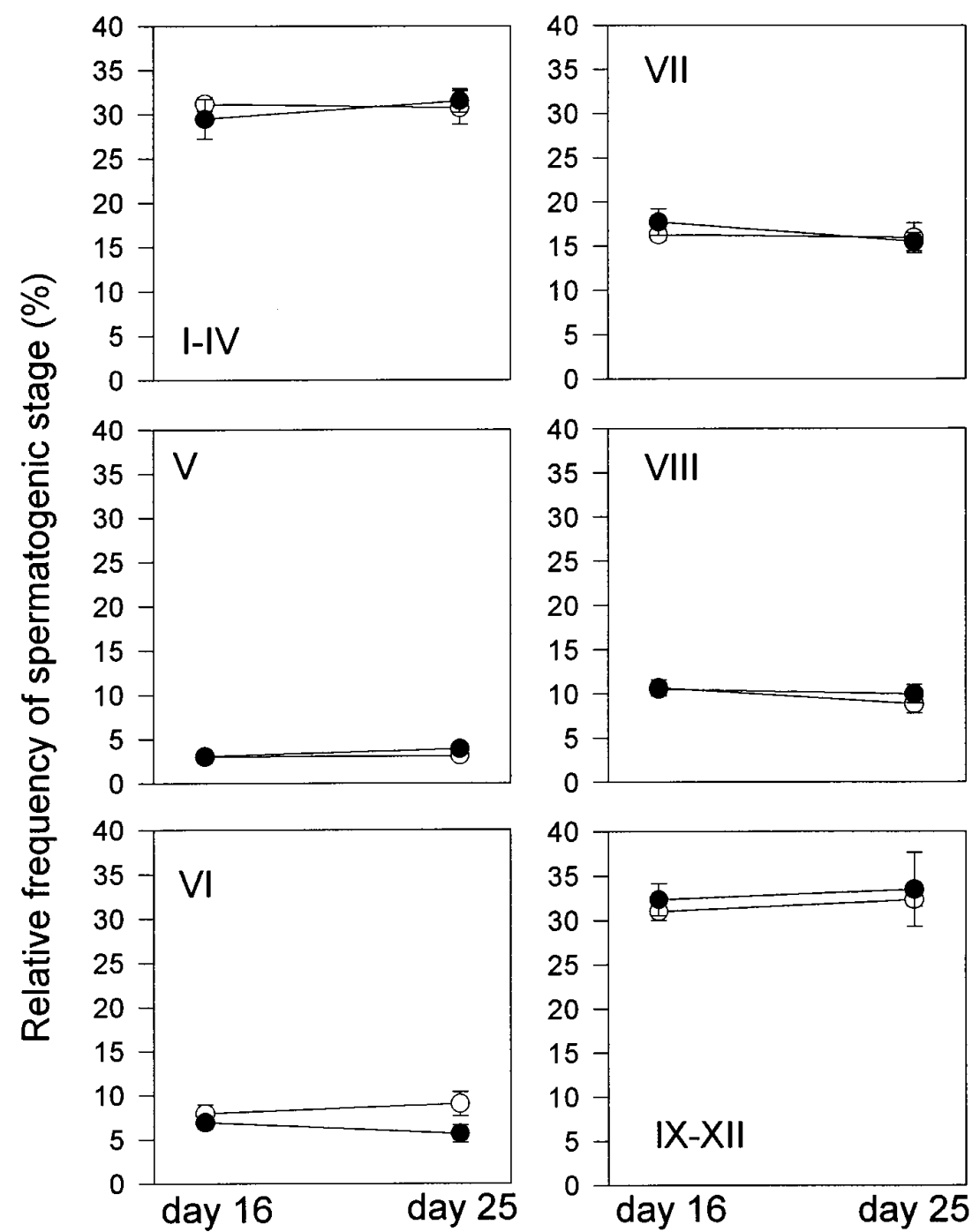

Figure 4 Relative frequency of spermatogenic stages on days 16 and 25 of VEH-treated (O) and ANT-treated (O) monkeys. Stages are denoted by Roman numerals. Data represent means \pm S.E.M. of four and five animals/group. Differences are not significant $(P>0 \cdot 05)$.

baseline to $6 \cdot 1 \pm 1.7 \mathrm{nmol} / 1$ within 7 days, $4 \cdot 4 \pm$ $1 \cdot 1 \mathrm{nmol} / 1$ by day 16 and $2 \cdot 8 \pm 0 \cdot 5 \mathrm{nmol} / 1$ by day 25 . Baseline inhibin levels were $7 \cdot 7 \pm 2 \cdot 4 \mu \mathrm{g} / 1$ and $9 \cdot 4 \pm$ $2 \cdot 6 \mu \mathrm{g} / 1$ in VEH and ANT groups respectively. Inhibin levels declined over time in both groups but this effect was significantly $(P<0 \cdot 05)$ more pronounced with ANT: $3 \cdot 4 \pm 1 \cdot 2$ in VEH vs $1.5 \pm 0 \cdot 2 \mu \mathrm{g} / 1$ in ANT group at termination of the study. On day 16 , testicular weights were $19 \pm 1 \mathrm{~g}$ in the VEH group and were reduced, albeit not significantly, to $14 \pm 2 \mathrm{~g}$ in the ANT-treated group $(P>0 \cdot 05)$. By day 25 , testis weight was $19 \pm 2 \mathrm{~g}$ in the VEH group and was further lowered with ANT to $10 \pm 1 \mathrm{~g}, P<0 \cdot 05)$.

\section{Discussion}

Kinetic parameters of cell proliferation, meiosis and haploid germ cell development, and the gonadotrophin control of these processes, were studied in a nonhuman primate model (cynomolgus monkey) using qualitative and quantitative histological analysis of BrdU-labelled meiotic and postmeiotic germ cells as well as dual parameter flow cytometry. Cetrorelix, a highly potent antagonist of $\mathrm{GnRH}$ in this macaque species (Weinbauer \& Nieschlag 1993) was used to inhibit gonadotrophic hormone secretion and the effectiveness of this treatment is evidenced by the reductions of serum testosterone 
and inhibin concentrations, and the decline of testis size.

By $3 \mathrm{~h}$ after BrdU injection, BrdU was localized to spermatogonia and early spermatocytes, by 9 days to spermatocytes and after 18 days to round spermatids. These observations demonstrate that early germ cells, having incorporated $\mathrm{BrdU}$ into their DNA, can progress beyond meiotic reduction division. Hence, a nonradioactive approach for tracing germ cells throughout the entire spermatogenic process is available for the nonhuman primate testis. An estimate of the duration of the spermatogenic cycle was derived from the 9-day and 18-day time points, i.e. the transition of spermatocytes into spermatids. Among control animals, the average duration of one cycle of spermatogenesis was $9 \cdot 8$ days. This value is similar to that obtained in the cynomolgus monkey by comparing BrdU-labelled germ cells $3 \mathrm{~h}$ and 9 days after BrdU $(9 \cdot 8$ days, $n=1$ (G Rosiepen, GF Weinbauer \& E Nieschlag, unpublished observation)). Based on thymidine labelling, the estimated length of the spermatogenic cycle was $9 \cdot 4 \pm 0 \cdot 3$ days $(n=4$, Dang 1971) and $10 \cdot 5$ and $10 \cdot 6$ days $(n=2$, Fouquet \& Dadoune 1986). Importantly, these comparative data indicate that the presence of BrdU had no adverse effect on the timing of the transitions from spermatocytes into spermatids in the present study.

The stage-dependent progression of BrdU-labelled germ cells was less advanced in the ANT-treated animals compared with VEH-treated animals. This is suggested by the observation that the frequency of stage V-VIII tubules containing BrdU-labelled round spermatids was reduced in gonadotrophin-deficient animals. Such a difference was unexpected since the timing of the spermatogenic cycle, including spermiogenesis, is believed to be independent of gonadotrophins (Clermont \& Harvey 1965). A decreased labelling rate of germ cells at the time of injection in ANT-exposed animals could potentially explain this difference. Qualitative analysis of the biopsates taken $3 \mathrm{~h}$ after BrdU did not support that suspicion. The similarity of proportions of BrdU-labelled spermatocytes and of BrdUstaining frequencies on day 9 after BrdU would also argue against an adverse early effect of ANT on BrdU incorporation. It is of interest to note, however, that the BrdUstaining frequency for stage VIII tubules on day 9 was, on average, about $20 \%$ for VEH and about $10 \%$ for VEH (Fig. 5). At this time point pachytene spermatocytes are labelled in stage VIII. This effect was not statistically different, but raises the possibility that ANT might have slightly affected the progression of these cells. Estimation of the duration of one cycle based on the interval $3 \mathrm{~h}$ and 9 days after BrdU could clarify this aspect. However, the limited amounts of biopsy material prohibit quantitative assessment. Therefore, the possibility of ANT-induced alterations of BrdU uptake and of meiotic germ cell development cannot be ruled out with certainty.

The observation of altered spermiogenesis could also be explained by assuming that, during ANT exposure, only those germ cells having incorporated BrdU are affected specifically during meiotic transition into spermatids and/or during spermiogenesis. This possibility cannot be discarded with ultimate certainty but is unlikely to account entirely for the observations based on the following considerations. The percentage of BrdU-labelled round spermatids in stage $\mathrm{V}$ and VI differed by about $30 \%$ suggesting that, if BrdU-labelled spermatids are primarily affected under ANT, this effect is not of substantial magnitude. The ratio of $1 \mathrm{C}: 4 \mathrm{C}$ cells was similar in the present study (25 days of ANT) and in a previous study (28 days of ANT) in the absence of BrdU (Weinbauer et al. 1991). Biased assessment of the stages of spermatogenesis owing to ANT-induced morphological changes is ruled out by the consistency of stage frequencies over time and the lack of difference between ANT and VEH groups. These data suggest that BrdU itself had no major detrimental effect on the formation and progression of haploid germ cells.

If spermatids are specifically retarded during spermiogenesis under ANT administration, the occurrence of atypical cellular association is to be expected. However, we could not detect such atypical cellular associations. It is conceivable, that the magnitude of such an effect was too slow to be detected by our approach. However, in the light of the findings and considerations discussed above, the possibility must also be considered, that slight alterations of spermatocyte development or BrdU incorporation under ANT exposure might well have contributed to the reduced progression of spermatids. The duration of one spermatogenic cycle was found to be prolonged by about one day but this effect was not statistically significant $(P=0.09)$. In an earlier investigation in the rat (Clermont \& Harvey 1965) it was observed that the duration of the spermatogenic cycle is not under gonadotrophic control, although it is of interest to note from that study, that the spermatogenic cycle duration increased slightly in the hypophysectomized rat and was reversed by administration of testosterone and even more so with human chorionic gonadotrophin (hCG). Circumstantial evidence for man (Heller \& Clermont 1964) does not support gonadotrophin control of the duration of the spermatogenic process: the progression of thymidine-labelled germ cells was compatible with the normal duration of spermatogenesis in one man with progestin-induced gonadotrophin deficiency and in another normal man treated with hCG. It remains unclear whether a hypogonadotrophic condition can indeed affect the duration of an entire cycle of spermatogenesis and further studies are necessary to clarify this issue.

Sertoli cells were consistently negative for BrdU, and peritubular and interstitial cells were rarely BrdU-positive. Hence, flow cytometric analysis of BrdU-tagged testicular cells essentially refers to germ cells. Since spermatogonia represent a main fraction of testicular 2C cells (Toppari et al. 1985), it is most likely that the majority of $2 \mathrm{C}-\mathrm{BrdU}$ 




Figure 5 Relative frequency of seminiferous tubules containing BrdU-labelled germ cells (BrdU-staining frequency) on days 16 and 25 in VEH-treated $(O)$ and ANT-treated monkeys. This data represent the quantitative analysis of the cell-specific and stage-specific distribution of BrdU as indicated in Fig. 2. Stages are denoted by Roman numerals. Data represent means \pm S.E.M. of four and five animals/group. ${ }^{a} P<0.05$ vs day 16 and ${ }^{\mathrm{b}} \mathrm{P}<0 \cdot 05$ vs $\mathrm{VEH}$.

cells on day 9 after BrdU (day 16 of the study) are spermatogonia that were in the S-phase at the time of BrdU application. Within only 16 days of ANT treatment, the relative number and the number of $2 \mathrm{C}-\mathrm{BrdU}$ cells per testis was significantly diminished. It would appear that ANT rapidly and pronouncedly inhibited spermatogonial proliferation in the nonhuman primate, possibly within a few days of initiation of treatment. The significant drop of 4C-BrdU cells (relative numbers and numbers per testis), representing either mitotic spermatogonia or meiotic spermatocytes, on day 16 further supports this view. Subsequent to this inhibitory effect on spermatogonial proliferation, spermatocytes and spermatids are progres- sively depleted over time as seen from the analysis of 4C-BrdU and $1 \mathrm{C}-\mathrm{BrdU}$ cells on day 25. These kinetic data suggest that ANT-induced germ cell depletion results from an arrest of spermatogonial divisions in the nonhuman primate. Our observations extend previous histological reports on the significant reduction of numbers of renewing spermatogonia after 28 days of ANT treatment (Weinbauer et al. 1991) but do not confirm the assumption of a meiotic arrest as the cause of spermatogenic inhibition (Aravindan et al. 1993). The data on proportions of 4C and $1 \mathrm{C}$ cells suggest that the number of cells available for meiosis is reduced by ANT, whereas the development into round spermatids is not prohibited. 
Gonadotrophin deficiency in the nonhuman primate induces a marked increase in the number of $2 \mathrm{C}$ cells if expressed as percentage of the total number of cells analyzed (Weinbauer et al. 1991, 1994, Aravindan et al. 1993); this increase, however, is relative resulting from the loss of $1 \mathrm{C}$ and $4 \mathrm{C}$ cells. In fact, expression of $2 \mathrm{C}$ cell numbers per testis yields reduced numbers. Analysis of BrdU-tagged cells is more representative to describe the $2 \mathrm{C}$ population since the percentage of $2 \mathrm{C}-\mathrm{BrdU}$ cells was also significantly decreased during ANT administration (Fig. 3, left panels). This issue becomes critical if ratios among the different cell populations, as indices of germ cell transformations, are based upon relative values; a 9-fold increase of the percentage of $2 \mathrm{C}$ cells along with unaltered percentage of $4 \mathrm{C}$ cells and a $>2$-fold decrease of the percentage of $1 \mathrm{C}$ cells in hypogonadotrophic monkeys was considered to indicate an arrest of meiosis (Aravindan et al. 1993). However, in the light of the findings from the present study using BrdU-tagged germ cells it is more likely that the loss of advanced germ cells per testis originates from an arrest of spermatogonial mitosis.

\section{Acknowledgements}

The GnRH antagonist cetrorelix was a generous gift of Dr Thomas Reissmann (ASTA Medica, Frankfurt, Germany). We are indebted to Sabine Forsthoff, Martin Heuermann, Agnes Rösner, Reinhild Sandhowe and Günter Stelke for their excellent technical assistance. Inhibin measurements were kindly provided by $\mathrm{Dr}$ Robert McLachlan, Prince Henry's Institute of Medical Research, Monash Medical Centre, Clayton, Australia. This study was supported by the Deutsche Forschungsgemeinschaft Confocal Research Group 'The Male Gamete: Production, Maturation, Function' (grant Ni-130/15-1, project V).

\section{References}

Aravindan GR, Gopalakrishnan K, Ravindranath N \& Moudgal NR 1993 Effect of altering endogenous gonadotrophin concentrations on the kinetics of testicular germ cell turnover in the bonnet monkey (Macaca radiata). Journal of Endocrinology 137 485-495.

Arslan MA, Weinbauer GF, Schlatt S, Shahab M \& Nieschlag E 1993 $\mathrm{FSH}$ and testosterone, alone or in combination, initiate testicular growth and increase the number of spermatogonia and Sertoli cells in a juvenile non-human primate (Macaca mulatta). Journal of Endocrinology 136 235-243.

Chandolia RK, Weinbauer GF, Fingscheidt U, Bartlett JMS \& Nieschlag E 1991a Effects of flutamide on testicular involution induced by an antagonist of gonadotrophin-releasing hormone and on stimulation of spermatogenesis by follicle-stimulating hormone in rat. Journal of Reproduction and Fertility 93 313-323.

Chandolia RK, Weinbauer GF, Simoni M, Behre HM \& Nieschlag E $1991 b$ Comparative effects of chronic administration of the nonsteroidal antiandrogens flutamide and casodex on the reproductive system of the adult male rat. Acta Endocrinologica 125 547-555.
Clermont Y \& Leblond CP 1959 Differentiation and renewal of spermatogonia in the monkey, Macacus rhesus. American Journal of Anatomy 104 237-273.

Clermont Y \& Harvey SC 1965 Duration of the cycle of the seminiferous epithelium of normal, hypophysectomized and hypophysectomized-hormone treated albino rats. Endocrinology $\mathbf{7 6}$ 80-89.

Dang DC 1971 Durée du cycle de l'épithelium séminifere du singe crabier, Macaca fascicularis. Annals de Biologie animale et Biochimie Biophysique 11 373-377.

Fingscheidt U, Weinbauer GF, Robertson DM, de Kretser DM \& Nieschlag E 1989 Radioimmunoassay of inhibin in the serum of male monkeys. Journal of Endocrinology 122 477-483.

Fouquet JP \& Dadoune JP 1986 Renewal of spermatogonia in the monkey (Macaca fascicularis). Biology of Reproduction 35 199-207.

Gopalkrishnan K, Kholkute S \& Anand Kumar TC 1987 Estimation of daily sperm production in rat and monkeys. Journal of Biosciences 12 93-97.

Heller CG \& Clermont Y 1964 Kinetics of the germinal epithelium in man. Recent Progress in Hormone Research 20 545-575.

Hoshino T, Nagashima T, Murovic J, Levin EM, Levin VA \& Rupp SM 1985 Cell kinetic studies of in situ human brain tumors with bromodeoxyuridine. Cytometry 6 627-632.

Johnson L, Petty CS \& Neaves WB 1980 A comparative study of daily sperm production and testicular composition in humans and rats. Biology of Reproduction 22 1233-1243.

Johnson L, Grumbles JS, Bagheri A \& Petty CS 1990 Increased germ cell degeneration during postprophase of meiosis is related to increased serum follicle-stimulating hormone concentrations and reduced daily sperm production in aged men. Biology of Reproduction 42 281-287.

Johnson L, Chaturvedi PK \& Williams JD 1992 Missing generations of spermatocytes and spermatids contribute to the low efficiency of spermatogenesis in humans. Biology of Reproduction 47 1091-1098.

van de Kant HJG \& de Rooij DG 1992 Periodic acid incubation can replace hydrochloric acid hydrolysis and trypsin digestion in immunogold-silver staining of bromodeoxyuridine incorporation in plastic sections and allows the PAS reaction. Histochemical Journal 24 170-175.

McLachlan RI, Wreford NG, de Kretser DM \& Robertson DM 1995 The effects of recombinant FSH on the restoration of spermatogenesis in the GnRH immunized adult rat. Endocrinology 136 4035-4043.

Marshall GR, Jockenhövel F, Lüdecke D \& Nieschlag E 1986 Maintenance of complete but quantitatively reduced spermatogenesis in hypophysectomized monkeys by testosterone alone. Acta Endocrinologica 113 424-431.

O'Donnell L, McLachlan RI, Wreford BG, de Kretser DM \& Robertson DM 1996 Testosterone withdrawal promotes stagespecific detachment of round spermatids from the rat seminiferous epithelium. Biology of Reproduction 55 895-901.

Rosiepen G, Weinbauer GF, Schlatt S, Behre HM \& Nieschlag E 1994 Duration of the cycle of the seminiferous epithelium, estimated by the 5-bromodeoxyuridine technique, in laboratory and feral rats. Journal of Reproduction and Fertility 100 299-306.

Rosiepen G, Chapin RE \& Weinbauer GF 1995 The duration of the cycle of the seminiferous epithelium is altered by administration of 2,5-hexanedione in the adult Sprague-Dawley rat. Journal of Andrology 16 127-135.

Rosiepen G, Arslan M, Nieschlag E \& Weinbauer GF 1997 Estimation of the duration of the cycle of the seminiferous epithelium in the non-human primate Macaca mulatta using the 5-bromodeoxyuridine technique. Cell and Tissue Research $\mathbf{2 8 8}$ 365-369.

Russell LD \& Clermont Y 1977 Degeneration of germ cells in normal, hypophysectomized and hormone-treated hypophysectomized rats. Anatomical Record 187 347-366. 
Russell LD \& Petersen RN 1984 Determination of the elongated spermatid-Sertoli cell ratio in various mammals. Journal of Reproduction and Fertility 70 635-641.

Sharpe RM 1994 Regulation of spermatogenesis. In The Physiology of Reproduction, edn 2, pp 1363-1434. Eds E Knobil \& JD Neill. New York: Raven Press.

Sinha-Hikim AP \& Swerdloff RS 1993 Temporal and stage-specific changes in spermatogenesis of rat after gonadotrophin deprivation by a potent gonadotrophin-releasing hormone antagonist treatment. Endocrinology 133 2161-2170.

Sun YT, Wreford NG, Robertson DM \& de Kretser DM 1990 Quantitative cytological studies of spermatogenesis in intact and hypophysectomized rats: identification of androgen-dependent stages. Endocrinology 127 1214-1223.

Thoolen B 1990 BrdUrd labelling of S-phase cells in testes and small intestine of mice, using microwave irradiation for immunogoldsilver staining: an immunocytochemical study. Journal of Histochemistry and Cytochemistry 3 267-273.

Toppari J, Eerola E \& Parvinen M 1985 Flow cytometric DNA analysis of defined stages of rat seminiferous epithelial cycle during in vitro differentiation. Journal of Andrology 6 325-333.

Weinbauer GF \& Nieschlag E 1988 Reversibility of GnRH agonist-induced inhibition of testicular function: comparison between rat, monkey and man. In LH-RH Agonists in Oncology, pp 91-103. Ed K Höffken. Berlin: Springer-Verlag.
Weinbauer GF \& Nieschlag E 1993 Comparison of the antigonadotropic activity of three $\mathrm{GnRH}$ antagonists (Nal-Glu, antide and cetrorelix) in a non-human primate model (Macaca fascicularis). Andrologia 25 141-147.

Weinbauer GF \& Nieschlag E 1996 The Leydig cell as a target for male contraception. In The Leydig Cell, pp 629-662. Eds AH Payne, MP Hardy \& LD Russell. Vienna: Cache River Press.

Weinbauer GF, Behre HM, Fingscheidt U \& Nieschlag E 1991 Human follicle-stimulating hormone exerts a stimulatory effect on spermatogenesis, testicular size, and serum inhibin levels in the gonadotropin-releasing hormone antagonist-treated non-human primate (Macaca fascicularis). Endocrinology 129 1831-1839.

Weinbauer GF, Limberger A, Behre HM \& Nieschlag E 1994 Can testosterone alone maintain the gonadotrophin-releasing hormone antagonist-induced suppression of spermatogenesis in the nonhuman primate? Journal of Endocrinology 142 485-495.

Wing TY \& Christensen K 1982 Morphometric studies on rat seminiferous tubules. American Journal of Anatomy 165 13-25.

Zhengwei Y, Wreford N \& de Kretser DM 1990 A quantitative study of spermatogenesis in the developing rat testis. Biology of Reproduction 43 629-635.

Received 18 April 1997

Accepted 25 July 1997 